\title{
IDENTIFICATION OF THE SHARKS OF THE GENUS Etmopterus RAFINESQUE, 1810 (ELASMOBRANCHII: ETMOPTERIDAE) FROM THE UPPER SLOPE OF SOUTHERN BRAZIL, WITH COMPARISON BETWEEN THE SPECIES E. BIGELOWI SHIRAI \& TACHIKAWA, 1993 AND E. PUSILLUS LOWE, 1839
}

\author{
Michel D. Gianeti ${ }^{1}$ and Carolus M. Vooren ${ }^{2}$
}

\author{
1 Instituto Oceanográfico da Universidade de São Paulo \\ (Praça do Oceanográfico, 191, 05508-120 São Paulo, SP, Brasil) \\ mgnine@hotmail.com \\ ${ }^{2}$ Fundação Universidade Federal do Rio Grande \\ Departamento de Oceanografia \\ (Caixa Postal 474, 96201-000 Rio Grande, RS, Brasil)
}

The genus Etmopterus Rafinesque, 1810 is the most diverse genus within the Squalomorphii and the Selachii as a whole, with 32 recognized species. These sharks are small to medium-sized, reaching 23 to $75 \mathrm{~cm}$ of total length in the adult phase (COMPAGNO, 1984; LAST; STEVENS, 1994). The species are widespread in temperate and tropical waters, have benthopelagic habits and occur mostly at depths of 200 to $2000 \mathrm{~m}$ (COMPAGNO, 1984; MUSICK et al., 2004).

Four Etmopterus species occur in Brazil: E. gracilispinis Krefft, 1968, E. lucifer Jordan \& Snyder, 1902, E. bigelowi, and E. granulosus Günther, 1880 (SADOWSKY et al., 1986; SOTO, 2000; SOTO 2001; BERNARDES et al., 2005). Only the three first species occur on continental slope of depths down to $600 \mathrm{~m}$. The occurrence of E. granulosus has been reported at depths greater than $2000 \mathrm{~m}$ (SOTO, 2001).

As these sharks have a complex taxonomy and have been little studied in Brazil, the purpose of the present work was to confirm the Etmopterus species occurring on the Rio Grande do Sul slope at depths down to $600 \mathrm{~m}$, with a taxonomic resolution of the species complex E. pusillus/bigelowi in the area.

In the scope of the Prospective Demersal Project of the "Score Sul REVIZEE Program" (BERNARDES et al., 2005), 152 specimens of the genus Etmopterus were collected. The study area included the outer continental shelf and the upper slope off the state of Rio Grande do Sul, between Chuí $\left(34^{\circ} 20^{\prime} \mathrm{S}\right)$ and the Cape of Santa Marta Grande $\left(28^{\circ}\right.$ $30^{\prime} \mathrm{S}$ ), at depths from 100 to $600 \mathrm{~m}$. Surveys were carried out by the R/V Atlântico Sul.

Soon after the catch, each specimen was classified according to Krefft (1968) criteria as Etmopterus gracilispinis, Etmopterus lucifer, or belonging to the Etmopterus pusillus/bigelowi complex for having characteristics common to $E$. pusillus and E. bigelowi, mainly the presence of truncated dermal denticles, which give the animal a smooth appearance. The specimens had their total length (TL) measured from the snout tip to the upper caudal lobe tip aligned with the body axis, and were then fixed in $10 \%$ formalin and preserved in $70 \%$ ethanol. The evidence material is kept in the "Laboratório de Elasmobrânquios e Aves Marinhas" of "Fundação Universidade Federal de Rio Grande (FURG)", RS - Brazil.

In the laboratory, using the criteria described by Krefft (1968), Shirai and Tachikawa (1993), Last and Stevens (1994) and Last et al. (2002), the field identification of the specimens classified as $E$. gracilispinis (Fig.1)(n=62; TL: $13.0-22.3 \mathrm{~cm})$ and E. lucifer (Fig. 2)(n=2; TL: $36.9-38.4 \mathrm{~cm})$ was confirmed.

The 88 specimens classified in the field as $E$. pusillus/bigelowi, were identified as E. bigelowi (Fig. 3)(TL: $17.4-67.0 \mathrm{~cm})$. For this specimens the turns in the intestinal valves were counted and some morphological proportions described by Shirai and Tachikawa (1993) and Last et al. (2002) were measured (being the distances between the points projected onto the body axis).

Specimens of E. gracilispinis showed slender, pointed dermal denticles that were not arranged in regular rows, and the dimensions of the head, the position of the pelvic fins, the intensity of the black markings on the body and the interdorsal space were according to the description of $E$. gracilispinis in Krefft (1968). In E. lucifer, the dermal denticles were also slender and pointed, but mostly arranged in longitudinal rows along the body, while the form and intensity of the black markings on the body and the length of the tail were according to the description of E. lucifer in Compagno (1984) and Last and Stevens (1994) 


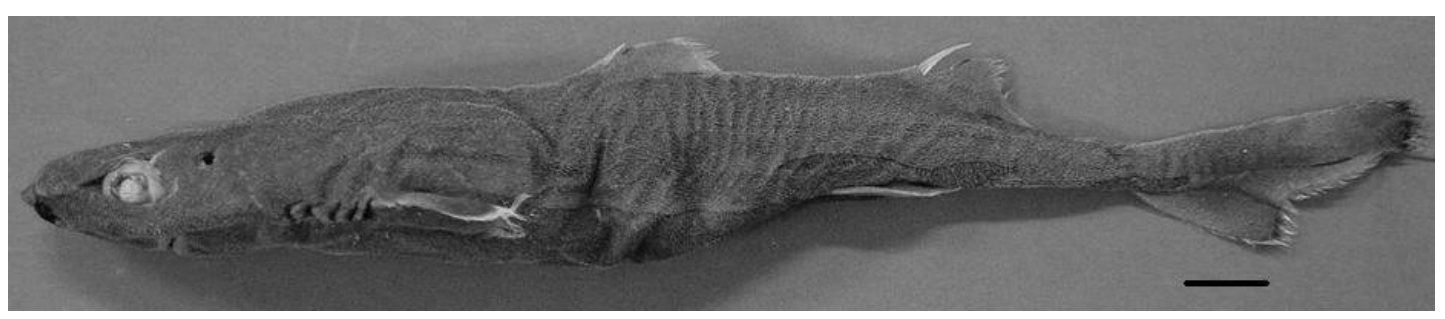

Fig. 1. Specimen of E.gracilispinis from Southern Brazil. Male; total length: $19.2 \mathrm{~cm}$; number: R7\#19N01 (440 m; 33ㅜㅇ' $\left.50^{\circ} 45^{\prime} \mathrm{W}\right)$. Scale $=1 \mathrm{~cm}$.

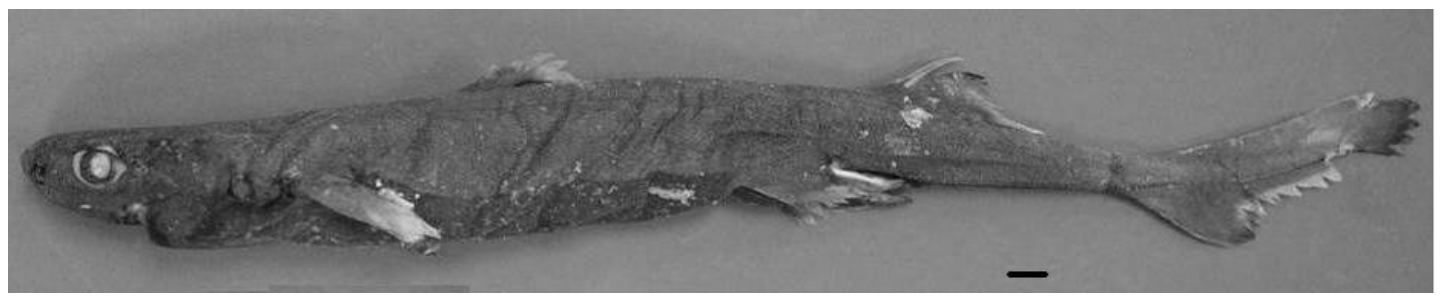

Fig. 2. Specimen of E. lucifer from Southern Brazil. Male; total length: $36.9 \mathrm{~cm}$; number: R7\#18N01 (538 m; $33^{\circ} 36^{\prime} \mathrm{S}$ $\left.50^{\circ} 44^{\prime} \mathrm{W}\right)$. Scale $=1 \mathrm{~cm}$.

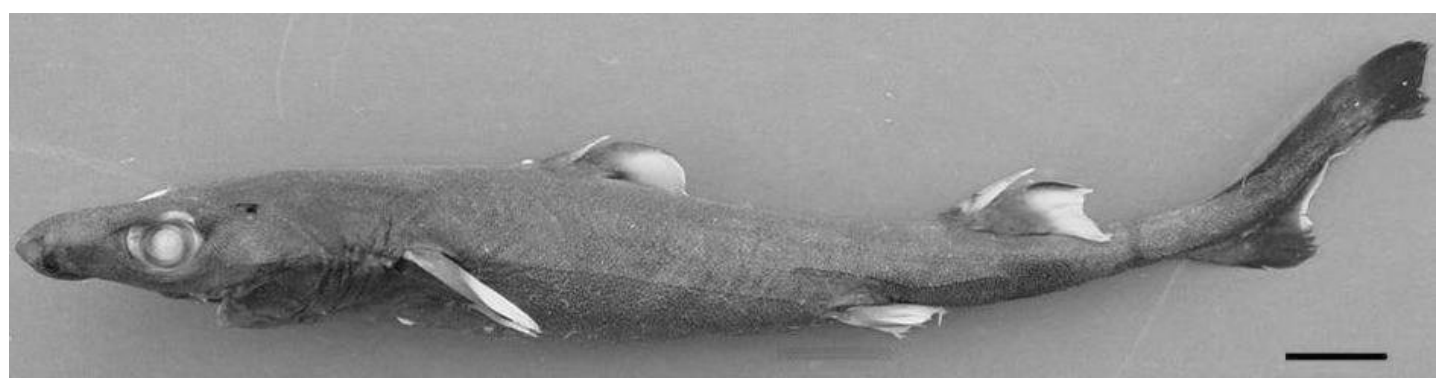

Fig. 3. Specimen of E. bigelowi from Southern Brazil. Female; total length: $17.4 \mathrm{~cm}$; number: R7\#15N13 (536 m; $34^{\circ} 17^{\prime} \mathrm{S}$ $\left.51^{\circ} 37^{\prime} \mathrm{W}\right)$. Scale $=1 \mathrm{~cm}$

Table 1 displays the diagnostic features of $E$. bigelowi and E. pusillus used as criteria for identifying each species. According to those criteria, the features of the specimens studied coincide with those of Etmopterus bigelowi, as follows:

- number of turns in the intestinal valves varying from 16 to 19 (average $=17$ );

- distance from the pectoral axil to the first dorsal fin origin equal to or shorter than $1 / 3$ of the interdorsal space (Fig. 4);

- distance from the free rear tip of pectoral fin to the first dorsal fin origin shorter than the horizontal eye diameter (Fig. 5);

- distance from the snout tip to the first gill slit (head length) longer than distance from the first gill slit to the first dorsal fin origin (Fig. 6);

- first dorsal fin spines of the analyzed specimens longer than those of E. pusillus (compared with literature data) and this difference increased with growth (Fig. 7).

Etmopterus gracilispinis, E. lucifer, and E. bigelowi occurred only to the south of latitude $31^{\circ} \mathrm{S}$. E. bigelowi occurred in the depth layer of 400 to 599 $\mathrm{m}$, and E. gracilispinis in the depth layer of 300 to 599 $\mathrm{m}$. The two specimens of E. lucifer occurred at depth of $540 \mathrm{~m}$. The bottom hydrographic conditions of temperature (5 to $100 \mathrm{C}$ ) and salinity ( 34 to 35 ) showed no seasonal differences and the species occurred on a sea bed consisting of clay and silt sediment.

Using Krefft (1968) and Last and Stevens (1994) criteria, it was possible to identify the specimens of E. gracilispinis and E. lucifer without difficulty. 
Table 1. Diagnostic features of Etmopterus bigelowi and Etmopterus pusillus used to identify specimens of E. pusillus/bigelowi complex.

Species

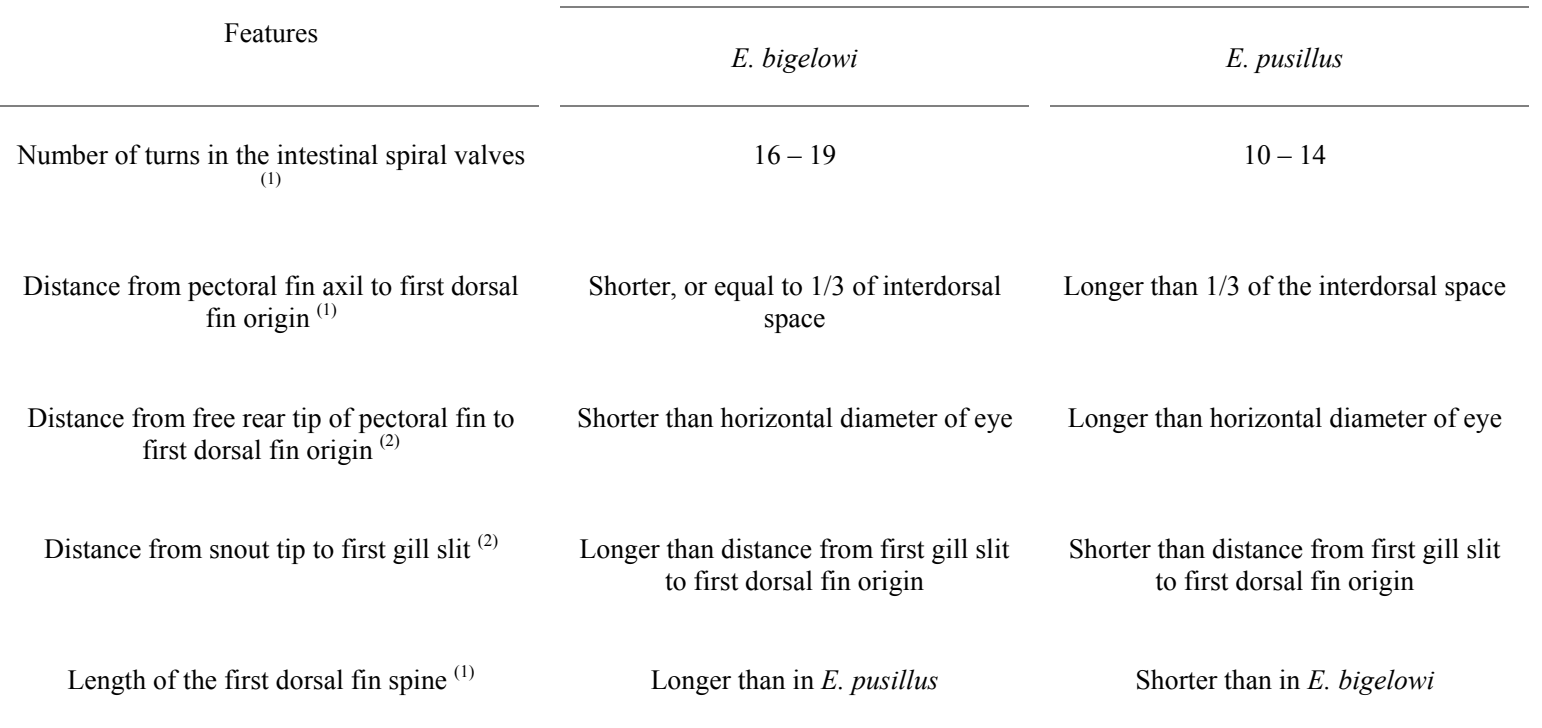

Sources: ${ }^{(1)}$ Shirai \& Tachikawa (1993); ${ }^{(2)}$ Last et al. (2002).

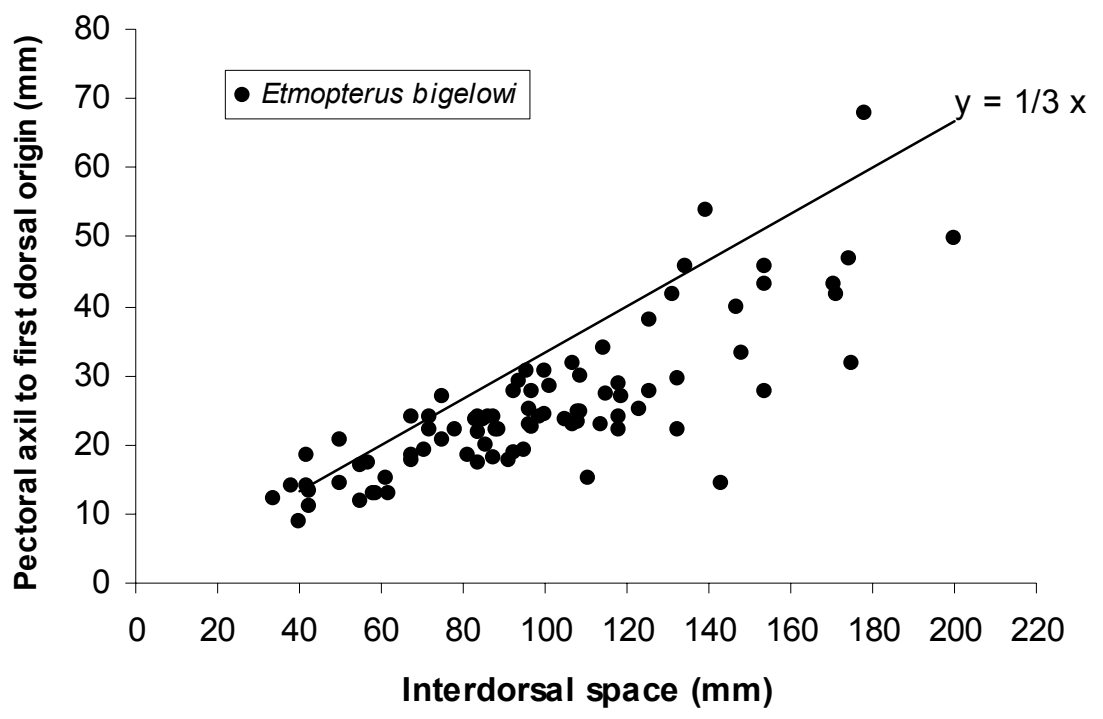

Fig. 4. Relationship between the distance from pectoral axil to first dorsal fin origin (y) and the interdorsal space $(x)$. Line means $y=1 / 3 x$. Black dots, which represent the proportions of 88 specimens from Southern Brazil, show that most y values are $\leq 1 / 3 \mathrm{x}$, which is characteristic of $E$. bigelowi, specially for larger specimens. 


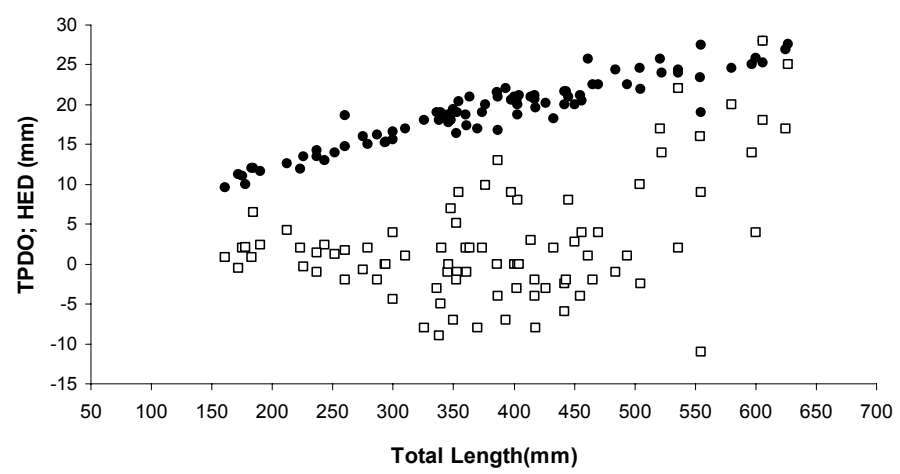

Fig. 5. Relationship between total length and horizontal eye diameter (HED, black dots) and between total length and the distance from free rear tip of pectoral fin to the first dorsal fin origin (TPDO, open squares), of 88 specimens from Southern Brazil. Notice that almost all values of TPDO are shorter than the values of HED, another characteristic of E. bigelowi.

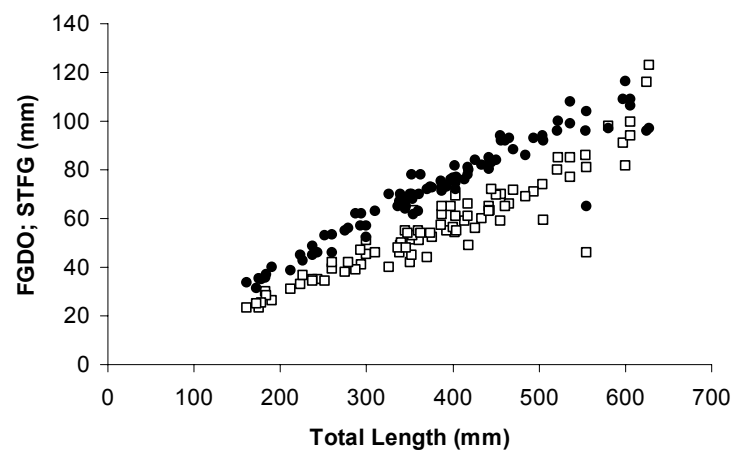

Fig. 6. Relationship between total length and distance from the snout tip to first gill slit (STFG, black dots) and between total length and distance from first gill slit to the first dorsal fin origin (FGDO, open squares), of 88 specimens from Southern Brazil. Notice the E. bigelowi feature in the specimens, with FGDO values shorter than STFG.

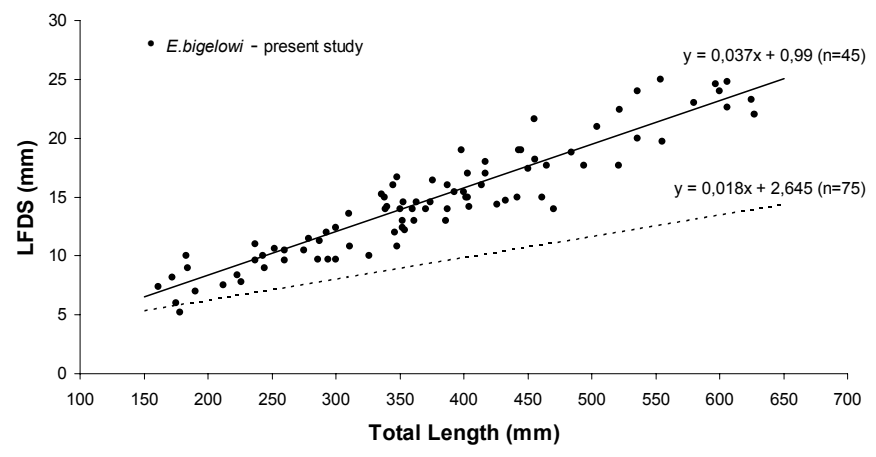

Fig. 7. Relationship between total length (TL) and the length of the first dorsal fin spine (LFDS), in 88 specimens from Southern Brazil, with the equations and lines of the regression LFDS-TL from E. bigelowi (solid line) and E. pusillus (dashed line) according to Shirai \& Tachikawa (1993). Notice that the values of the Brazilian specimens are distributed around the line for E. bigelowi. 
The identification of E. bigelowi is more complicated because of the many features that the species has in common with E. pusillus. However, using the Shirai and Tachikawa (1993) criteria, which describe the species E. bigelowi, and with the criteria cited by Last et al. (2002), it was possible to obtain a reliable identification of the specimens belonging to the species E. bigelowi. The most consistent feature seems to be the number of turns in the intestinal spiralvalves, as such data do not show overlap between the species E. bigelowi and E. pusillus in any length class. This characteristic can also be seen in the data cited by Shirai and Tachikawa (1993).

The morphological relationship values presented in Figures 4, 5,6 and 7, which are situated on the line for E. pusillus, were probably due to shrinkage of some of the fixed specimens; and in the case of first dorsal spines, because of damage that occurred to a few specimens during the fishing process. However, none of these errors caused problems to all the morphological relationships and were not repeated for the same specimens in all measurements.

Krefft (1968) described the occurrence of $E$. gracilispinis, E. lucifer and E. pusillus in Uruguayan waters. Nevertheless, some of the occurrence sites mentioned by Krefft (1968) are situated in Brazilian waters (SOTO, 2000), and therefore were the first records of these three species for Brazil.

However, Shirai and Tachikawa (1993), from the analysis of the morphological data cited by Krefft (1968), concluded that the first occurrence of $E$. pusillus, described coincidentally for southern Brazil, actually refers to specimens of $E$. bigelowi.

The results obtained confirm that the three species of the genus Etmopterus common on the upper slope off southern Brazil at depths down to $600 \mathrm{~m}$ are E. gracilispinis, E. lucifer and E. bigelowi, while the presence of $E$. pusillus remains to be confirmed.

\section{AcKNOWLedgements}

We acknowledge the researchers of the "Score Sul REVIZEE Program" who contributed to the fishery surveys, the $R / V$ Atlântico Sul crew, and the Conselho Nacional de Desenvolvimento Científico e Tecnológico (CNPq) for the scholarship provided.

\section{REFERENCES}

BERNARDES, R. A.; FIGUEIREDO, J. L.; RODRIGUES, A. R.; FISCHER, L. G.; VOOREN, C. M.; HAIMOVICI, M.; ROSSI-WONGTSCHWSKI, C. L. D. B. Peixes da Zona Econômica Exclusiva da região sudeste-sul do Brasil: Levantamento com armadilhas, pargueiras e rede de arrasto de fundo.São Paulo: EDUSP, 2005. 304 p.
COMPAGNO, L. J. V. Sharks of the world: An annoted and illustrated catalogue of shark species known to date. Part 1: Hexanchiformes to Lamniformes. Rome: FAO, 1984. 249 p. FAO Species Catalogue, v. 4, n. 1. FAO Fisheries Synopsis, n. 125.

GÜNTHER, A. Report on the shore fishes procured during the voyage of H. M. S. "Challenger" in the years 18731876. Report on the Scientific Results of the Voyage of H. M. S. Challenger, Zoologie , v. 1, n. 6, p. 1-8, 32 pls, 1880.

JORDAN, D. S.; SNYDER J. O. Descriptions of two new species of squaloid sharks from Japan. Proc. U. S. natn. Mus., v.25, n. 1279, p. 79-81, 1902.

KREFFT, G. Neue und erstmalig nachagewiesene Knorpelfishe aus dem Archibenthal des Südwestatlantiks, einschlie lich einer Diskussion einiger Etmopterus - Arten südlicher Meere. Arch. Fischereiwiss., v. 19, p. 1-42, 1968.

LAST, P. R.; STEVENS, J. D. Sharks and rays of Australia. East Melbourne: Commonwealth Scientific Industrial Research Organization (CSIRO), 1994. 513 p.

LAST, P. R.; BURGESS, G. H.; SÉRET, B. Description of six new species of lantern-sharks of the genus Etmopetrus (Squaloidea: Etmopteridae) from the Australasian region. Cybium, v. 26, p. 203-223, 2002.

LOWE, R. T. A supplement to a synopsis of the fishes of Madeira. Proc. Zool. Soc. of Lond., v. 7, p. 76-92, 1839 (also publ. in Trans. zool. Soc. Lond., v. 3, n. 1, p. $1-20,1842)$.

MUSICK, J. A.; HARBIN, M. M.; COMPAGNO, L. J. V. Historical zoogeography of the Selachii. In: CARRIER, J. C.; MUSICK, J. A. HEITHAUS (Ed.). Biology of sharks and their relatives. Boca Raton, Fla.: CRC Press, p. 55-60, 2004.

RAFINESQUE, C. S. Caratteri di alcuni nuovi generi e nuove specie di animali e piante della Sicília, com varie osservazioni sopra i medisimi. Palermo: 1810. $105 \mathrm{p}$.

SADOWSKY, V.; ARFELLI, C. A.; AMORIM, A. F.. First record of broadbanded lanternshark, Etmopteurs gracilispinis Krefft, 1968 (Squalidae), in the Brazilian waters. Bol. Inst. Pesca, São Paulo, v. 13, n. 2, p. 1-4, 1986.

SHIRAI, S.; TACHIKAWA, H. Taxonomic resolution of the Etmopterus pusillus species group (Elasmobranchii, Etmopteridae), with a description of E. bigelowi, n. sp. Copeia, v. 2, p. 483-495, 1993.

SOTO, J. M. R. Revisão da ocorrência de tubarões etmopteríneos na costa brasileira, com dois novos registros de Etmopterus bigelowi Shirai \& Tachikawa, 1993 (Chondrichtyes, Dalatiidae, Etmopiterinae). Biotemas, v. 13, n. 2, p. 167-178. 2000.

SOTO, J. M. R. First record of southern lanternshark Etmopterus granulosus (Günther, 1880) (Squaliformes, Dalatiidae), in Brazilian coast. Mare Magnum, v.1, n. 1, p. 7-10, 2001.

(Manuscript received 30 May 2007; revised 24 August 2007; accepted 12 November 2007) 